\title{
EGIPTO, EN TRES DIMENSIONES
}

\author{
Rosa-Isabel Martínez Lillo
}

\section{INTRODUCCIÓN.}

2. EGIPTO, EN TRES DIMENSIONES:

2.1. PASADO: Ahmad Šawqī ("Himno al Nilo")

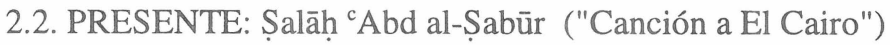

2.3. FUTURO: Amal Dunqul ("Salmos")

3. EPÍLOGO.

\section{INTRODUCCIÓN.}
"Alrededores de la casa, del centro, del barrio que estoy viendo y por donde paseo, años y años.
Os he creado en la alegría y en las penas: con tantas circunstancias, con tantas cosas.
Y enteros, para mí, en sentimientos os habéis transformado"11

Sirva este poemita del griego Constantino Kavafis, titulado "En el mismo espacio", como umbral a nuestro escrito. En verdad, siempre que un sujeto habite un cierto espacio va a darse una relación, sujeto-espacio, en que, más allá de la propia personalidad de este sujeto y de la idiosincrasia de aquel espacio, nacerán entes con nombre propio, sentimientos muy particulares. Mejor aún, el sujeto y el objeto, la persona y el espacio, se imbricarán, se entremezclarán de tal manera que será muy difícil llegar a delimitar las fronteras de ambos.

\footnotetext{
${ }^{1}$ Kavafis: Kavafis, antología poética, edición trilingüe, prólogo y traducción castellana de Ramón Irigoyen, traducción catalana de Carles Riba y Alexis E.Solà, Ayuntamiento de Valencia, Valencia, 1984, p.203. El título del poema es "En el mismo espacio".
} 
En nuestro caso particular nos encontramos, por una parte, con un sujeto, una persona que vivió una realidad precisa en un momento preciso, y, por otro, con un objeto, aquella realidad, un país: Egipto.

Egipto, país sin par en el que, como apunta uno de sus grandes conocedores, Gamāl Hamdān, geografía e historia caminan cogidas de la mano, donde es imposible intentar comprender y sentir la una sin la otra, y donde, finalmente, ambas irán conformado, junto con el elemento cultural, lingüístico, de civilización, la manera de estar, ser y existir de todo un pueblo.

Egipto, país incomprensible sin su extensa y superpoblada capital: El Cairo, acaso su tiempo presente; y su ciudad-espejo o salida al Mediterráneo, al exterior: Alejandría, tal vez su tiempo futuro...El Cairo, bulliciosa, llena de gente hasta más no poder ("muzdahima"), y Alejandría, un tanto más serena, salvo en la época estival en que una gran cantidad de la población cairota acude a sentir en la piel esa humedad "alejandrí" ("ruṭūba"), ésa que sólo allí se encuentra.

Egipto: El Cairo y Alejandría unidas, ¿cómo no?, por el eje vivo y vivificante de toda la zona: El Nilo. El Nilo, fuente de vida. El Nilo, nexo. El Nilo, Historia.

El Cairo, Alejandría y el Nilo, por lo tanto, como tres elementos primordiales, creemos, a la hora de intentar adentrarnos en el país único que es Egipto. Tres entes que todos aquellos que vivieron, que vivimos, en esta realidad tan singular siempre llevarán, llevaremos, grabados en el corazón. Tres entes inolvidables, como inolvidables son, recordando ahora la figura del genial Tawfīq al-Hakīm, la gorra, el bastón y el gato, de quienes se acompañaba dicho autor egipcio. Los tres elementos de Egipto, entonces, como los tres elementos "tawfiquíes", valga la expresión; mas no hay que olvidar, llegados a este punto, aquellos ojos de mirada tan transparente del literato egipcio, ¿fruto de reflexión?, y aquella su sonrisa socarronamente fresca, ¿fruto de sentimiento? ¿Reflexión y sentimiento del ser, del sujeto, íntimamente vinculados al espacio, al objeto?

\section{2. EGIPTO, EN TRES DIMENSIONES.}

Nos ocuparemos aquí y ahora de las tres entidades primordiales egipcias: El Nilo, El Cairo y Alejandría, a partir de tres poetas egipcios de generaciones diferentes: Aḥmad Šawqī (1868-

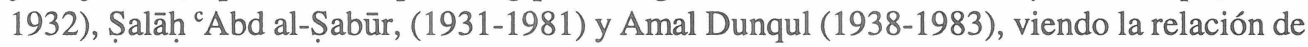
cada uno de los autores (los sujetos), con cada uno de los elementos (los objetos), a partir de la creación poética. A tal efecto, hemos elegido tres de los poemas más ilustrativos de cada uno de ellos: "Himno al Nilo", de Ahmad Šawqī, "Canción a El Cairo", de Șalāḥ cAbd al-Ṣabūr, y, para terminar, "Salmos", de Amal Dunqul, analizando, en cada uno, la dimensión temporal que más pataentemente aparece, esto es, y respectivamente, el Pasado, el Presente y el Futuro. 
2. 1. PASADO: Ahmmad Šawqī ("Himno al Nilo").

¿¿Desde qué época riegas los campos con tus aguas?

¿y cuál es esa mano que colma las ciudades?

¿Has bajado del cielo?

¿De lo alto del Edén brotaron tus arroyos?

Tus aguas desbordadas, ¿de qué nube o diluvio?

¿En qué telar tejiste el manto siempre nuevo

que cubre eternamente tus orillas?

¿Cuando Tú te retiras

queda mustio y ajado,

lo mismo que una tela que su color perdiera;

pero al llegar de nuevo,

¡cómo brilla su seda de riente color!

Cada estación del año, ¡oh, maravilla!,

va mudando la tierra de colores.

Y tan sólo Tú, Nilo,

eres quien va tiñiendo tus vestidos.

Las edades quisieron agotarte,

mas tu cuna de agua aún sigue llena,

y en los hondos aljibes se ha seguido vertiendo

la linfa deseada.

Escancias y alimentas

-tus vasos rebosantes,

tu mesa siempre llena de manjares-

a todo el que te llega hasta saciarlo.

El agua que repartes se funde como el oro,

y las tierras que anegas

con más riqueza salen a la vida"

(Trad. P.Martínez Montávez)².

En este poema, en el que, como indica su traductor, el Profesor Pedro Martínez, "el país natal del poeta...alcanza su punto de plenitud"3 ${ }^{2}$ Šawqī no hace sino poner de manifiesto las dos características esenciales del río: su carácter histórico, temporal, a-temporal en este caso, y su elemento promordial, el agua.

El Nilo, en efecto, fluye al unísono de su historia, de la historia de Egipto: ¿¿Desde qué época...?", "Las edades quisieron agotarte...". El río, por lo tanto, encarna el pasado, la historia. Y a esta historia precisamente va a ser a quien done su contenido: el agua. Agua como sinónimo de vida: "Escancias y alimentas/ -tus vasos rebosantes,/ tu mesa siempre llena de

${ }^{2}$ Pedro Martínez Montávez: Introducción a la literatura árabe moderna, pp.57-58.

3 Idem., p. 57 
manjares/ a todo el que te llega hasta saciarlo./ $\mathrm{El}$ agua que repartes se funde como el oro,/ y las tierras que anegas/ con más riquezas salen a la vida."

El Nilo, sí, es, heredero de un pasado singular e inimitable que continúa vivo. Heredero de una vida que fluye por sus cuatro costados, inconmensurable, desbordante como sus aguas (digamos, en este sentido que en el texto original árabe el plano fonético está íntimamente relacionado con el semántico ya que la aliteración de sonidos guturales, como la letra "gayn" por ejemplo, no es sino una onomatopeya del agua que todo lo anega).

En definitiva, vemos cómo Šawqī, el "Príncipe de los poetas", condensa todo el país, Egipto, en su caudaloso río, el Nilo, y cómo este Nilo simboliza toda una historia, todo un pasado, todo un "turāt".

\section{2. PRESENTE: Șalāh ${ }^{\mathrm{c} A b d}$ al-Ṣabūr ("Canción a El Cairo")}

(Después de un mes de ausencia)

"Encontrate de nuevo, ¡ciudad mía!, es mi peregrinar

y mi sitio de llanto.

Encontrarte de nuevo, ¡ciudad mía!,

es mi tristeza.

Y cuando vi a través del aeropuerto en sombras

tu luz, jay, ciudad mía!,

supe que estaba atado a tus calles de asfalto,

a esas plazas en cuya llama muere

lo verde de mis días.

Que lo que tengo escrito, joh, mi herida creciente!, es volver a encontrarte, cada vez que me aleje de ti, con el alma sedienta.

Que sea mi manatial de inspiración

lo que tú me regales, o el dolor que le asignes al corazón.

Que me disuelva en ti al final de mis días.

Y que el Nilo y las islas que lo surcan,

el aceite, las muchedumbres y las piedras,

reúnan ya mis huesos diseminados

por las calles de asfalto,

por el polvo de barrios y callejas:

Cuando ya todo vaya en mi ataúd de sicomoro egipcio.

Encontrarte de nuevo, ciudad mía, me deja el corazón sin fuerzas y apretado:

Como cuando desea, o tiene miedo, o hambre.

Encontrarte de nuevo me sacude.

Encontrarte, es un llanto.

Te amo, ciudad mía, con el amor brillante de los ojos que lloran, saciándose en la vista del amado.

Te amo, ¡ciudad mía!, con ese amor que entiende 
que su voz contenida

pueda decir tan sólo dos palabras

cuando quiere ser franca.

Te amo, ciudad mía.

A pesar de que me negaron por tus ámbitos

y de que me dejó mi pajarillo.

Y vuelvo...Sin morada ni refugio.

Vuelvo para escaparme por tus puertas.

Vuelvo para beberme tu tormento"4.

El poeta, aquí, desde una perspectiva de madurez, canta a su amada Cairo, su ciudad, viviéndola, palmo a palmo, en un tiempo presente. El Cairo se torna, entonces, en sus realidades más físicas e inmediatas: sus calles, sus muchedumbres, sus piedras. Es como si ciudad y poeta fueran, unidos en simbiosis, una única realidad, un tiempo y espacio únicos: único ámbito vital. Nada importa el pasado, la ausencia vivida, ni lo que ha de llegar, ¿quién conoce el futuro?; tan sólo el presente, ese vínculo que ahora siente ${ }^{\mathrm{C}} \mathrm{Abd}$ al-Șabūr por todos los poros de su piel, es lo que existe.

2. 3. FUTURO: Amal Dunqul ("Salmos")

\section{(SALMO PRIMERO)}

"¿Estoy enamorado de Alejandría, Alejandría está enamorada del aroma del mar, y el mar, de una joven seductora en las lejanas costas!

Cada tarde, se desliza a mi lado, se despoja de todas sus prendas, se suelta las trenzas, ¡después se echa a la calle, desnuda, bajo la lluvia! Cuando se acerca al lecho del ay del dolor se tira en sus túnicas de espuma, ¡y, abierta, espera!

Sigue, hasta la aurora, extendida, cual llamada, tensa, como la cuerda.

¡iY continúa...sola!!

(SALMO SEGUNDO)

Le dije en la lluviosa noche:

${ }^{4}$ Traducción de Pedro Martínez Montávez en:Ṣalāh ${ }^{c} A b d$ al-Ṣabūr: Poemas, Instituto Egipcio de Estudios Islámicos, Madrid, 1982, pp. 10-11. 
el mar es una araña

y tú, en su red, mariposa que muere.

Se agitó como la gata fugitiva,

se alzó vibrando con el viento y las olas

(dos pechos de cristal

y un cuerpo de marfil)

y se escapó bogando, viajando hacia lo ignoto

sobre espuma picada.

¡Llamé, no contestó!

¡Grité, no se volvió!

(Al tiempo que ella mi voz desvanecióse

tras la rompiente ola)

\section{(SALMO TERCERO)}

El mar echó sus órganos en una mañana dolorosa,

y yo vi las heridas,

vi sus sangrientas uñas

girando en un mechón "dorado",

llené de arena sus heridas,

las calenté con el licor de las viñas...

Cada tarde

se desliza con la pleamar, con la hora lunar,

descansa sobre la eterna roca,

escucha la ironía de la ola debajo de sus pies, la sirena de barcos viajando por lo negro caliente,

van subiendo a sus labios salados los vientos del simún, sus lágrimas caen como dardos

y los astros

$$
\begin{aligned}
& \text { (hundidos en el fondo) } \\
& \text { suben, uno tras otro, } \\
& \text { y los va recogiendo } \\
& \text { contando las estrellas } \\
& \text { ¡Esperando el antiguo amor! }
\end{aligned}
$$

(SALMO CUARTO)

...jQué cruel es mi espera!

Mi corazón es un reloj de arena amarillo

por cuyas entrañas cae la arena, poco a poco

¡iQizá la arena tenga, a veces, sabor a sal, sabor a espera!!.

\section{(SALMO QUINTO)}

Tu falda de verano era de lino

y una flor blanca llevabas en el pecho, pero ahora el invierno te ha vestido de tifus ( $i$ Incluso la hoja de morera en tus muslos

$$
\text { está amarilla!)... }
$$




\section{(SALMO SEXTO)}

Somos dos voces...

(¿Es que la voz se ha convertido en dos?)

Nos paseamos por el ecuador de la muerte, recogimos violetas, trepamos por los rayos del placer, sacudimos los cerrojos de las casas golpeamos las piedras del amor, nos sentamos brillantes;

así, acude tú en mi nombre, en nombre de la araña, en nombre del retorcido grabado de recuerdos

y su cúmulo escalonado.

Una hoja de morera, caída de las vergüenzas del verano, continúa esperando.

Nos paramos a mirar

(sin pestañear) hasta que cayó al río... ¡Volvió el silencio!

\section{(SALMO OCTAVO)}

¿Por qué me sigue adonde quiera que vaya la voz del violín?

Encuentro a la que me despidió de pie a la orilla del río.

En sus ojos se posan unas extrañas tórtolas, y unas perdices se zambullen por sus manos.

Te amo.

El violín se ha vuelto culata de fusil, y las tórtolas del huerto, bombas que caen a cada instante. ¡Y se alejó el violín!"5.

El extenso poema, del que insertamos un estracto, comienza citando a la mediterránea Alejandría y este ambiente marítimo, además de las imágenes más o menos visionarias, será el que prime en todo él. La "Alejandría, de los años de niñez", a la que Dunqul dedicará otro de sus divanes, será, en efecto, el escenario idóneo en el que se desarrolle su vida juvenil. Vida, sí, de pesares y tristezas, no hay que olvidar que el poeta estaba aquejado de cáncer desde pequeño, mas vida, también, de entusiasmo, de enardecimientos, de pasiones, de futuro, en último caso. Y es que esta ciudad de soleados atardeceres transparentemente amarillos se tornará en Dunqul en deseo de futuro, de vida, a pesar de todo, contrariamente a lo que supusieron en su experiencia vital ciudades como Port $\mathrm{Sa}^{\mathrm{c}} \mathrm{id}$ o El Cairo.

Alejandría, en fin, puerto de mar y, así, de vida futura.

5 El "Salmo octavo" está traducido por Carmen Ruiz Bravo-Villasante en La muerte de la luna y otros poemas, Instituto Egipcio de Estudios Islámicos, Madrid, 1984 ; el resto de los Salmos son traducción nuestra y se encuentran en nuestra Tesina:Amal Dunqul: vida y obra, dirigida por la citada Profesora C. Ruiz, presentada en la U.A.M., Madrid, 198 5, pp. 449-454. 


\section{EPÍlOOGO.}

Tres visiones, entonces, de Egipto. Tres ámbitos temporales, del mismo modo, de Egipto. Egipto, en nuestro caso, como complemento a una Sevilla de cielos blanquecinos en la que ya se huelen aromas del Atlántico, en la que ya se vislumbran las puertas del paraíso, ¿no es el umbral, Sevilla, al paraíso?

Acaso el Nilo no se encuentre tan lejos del Guadalquivir; acaso las mil y una pisadas de las calles de El Cairo no se distancien tanto de las mil y una pisadas camperas y de tacones de Sevilla en abril; acaso la mediterránea Alejandría sea el complemento idóneo a la atlántica Sevilla. Tal vez. ¿Quién sabe? La respuesta está en el corazón de la persona. 